\begin{tabular}{c} 
Volume and Issues Obtainable at Center for Sustainability Research and Consultancy \\
Journal of Business and Social Review in Emerging Economies \\
ISSN: 2519-089X (E): 2519-0326 \\
Volume 3: Issue 2December 2017 \\
CSRᄃ \\
Journal homepage: $\underline{\text { www.publishing.globalcsrc.org/jbsee }}$ \\
\hline
\end{tabular}

\title{
The Islamic Philosophical Perspective on Hajj Pilgrim Management
}

\section{${ }^{1}$ Musmuliadi Kamaruding, ${ }^{2}$ Mohd Syahmir Alias, ${ }^{3}$ Abang MohdRazifAbangMuis, ${ }^{4}$ Mohammad ZulfakhairiMokthar}

\author{
${ }^{1}$ Lecturer, Facultyof Business and Management, DRB-HICOM University of Automotive \\ Malaysia.musmuliadi@dhu.edu.my \\ ${ }^{2}$ Lecturer, Philosophy and Civilization Section, School of Humanities, UniversitiSains Malaysia.syahmir@usm.my \\ ${ }^{3} \mathrm{PhD}$ Scholar, Centre for Islamic Development Management Studies, UniversitiSains Malaysia. \\ abgmohdrazif@gmail.com \\ ${ }^{4}$ Lecturer, Department Business, Faculty of Management Studies, KolejUniversiti Islam Pahang Sultan Ahmad \\ Shah Malaysia.zulfakhairi@yahoo.com
}

\begin{tabular}{l}
\hline ARTICLEDETAILS \\
\hline History \\
Revised format: Nov 2017 \\
AvailableOnline: Dec 2017
\end{tabular}

\section{Keywords}

Hajj pilgrim management,

Islamic ontology,

Islamic epistemology,

Islamic axiology,

Islamic teleology

\section{JEL Classification:}

J53, J59

\begin{abstract}
Purpose:Hajj is the fifth pillar of Islam. Every year, during the hajj season, millions of pilgrims came from different countries and gathered in Mecca to perform hajj. The huge numbers of pilgrims have made the management of pilgrims became too complex. The management itself is also not reasonable if it not based on the Islamic philosophical basis. In other words, the most suitable management practice in managing pilgrims in Mecca is the management from the Islamic philosophical perspectives. Therefore, this paper aims to identify and to analyze the philosophy of hajj pilgrim management from Islamic perspectives. This paper employed document research method and was analyzed with content analysis method. The result found that the philosophy of hajj pilgrim management from Islamic perspective can be identified based on four elements. The first element is epistemological aspect by referring to Qur'an and hadith as the authoritative source of knowledge. Secondly, ontological aspect which assert monotheism (tawhid) as the management mound. Thirdly, axiological aspect with the application of values in management such as excellence (ihsan), trust (amanah), and justice (' $a d l$ ). Fourthly, teleological aspect which emphasizes the pleasure of Allah (mardati'Llah) as the ultimate goal of hajj pilgrim management. In conclusion, to emphasize on these four elements of Islamic philosophy in hajj pilgrim management in Mecca is important to ensure the management activities that carried out will always gain the pleasure of Allah SWT.
\end{abstract}

(C) 2017 The authors, under a Creative Commons AttributionNonCommercial 4.0

Corresponding Author's Email: musmuliadi@dhu.edu.my

Recommended citation:Kamaruding, M., Alias, M.S., Muis,A.M.R.A.\&Mokthar,M.Z., (2017). The Islamic Philosophical Perspective on Hajj Pilgrim Management.Journal of Business and Social Review in Emerging Economies, 3 (2) 235-244.DOI:https://doi.org/10.26710/jbsee.v3i2.42

\section{Introduction}

The early history of hajj during the time of Prophet Muhammad SAW only involved hundred thousand of people. The numbers however have changed and increases up to millions of people nowadays (AlHashedi, Muhammad RafieMohd Arshad, Hasimah Mohamed \& Ahmad SuhaimiBaharudin, 2013). To 
shows the increase in numbers of pilgrims, Figure 1 is showing the total statistics of pilgrims in Mecca for the year 2010 until 2014.

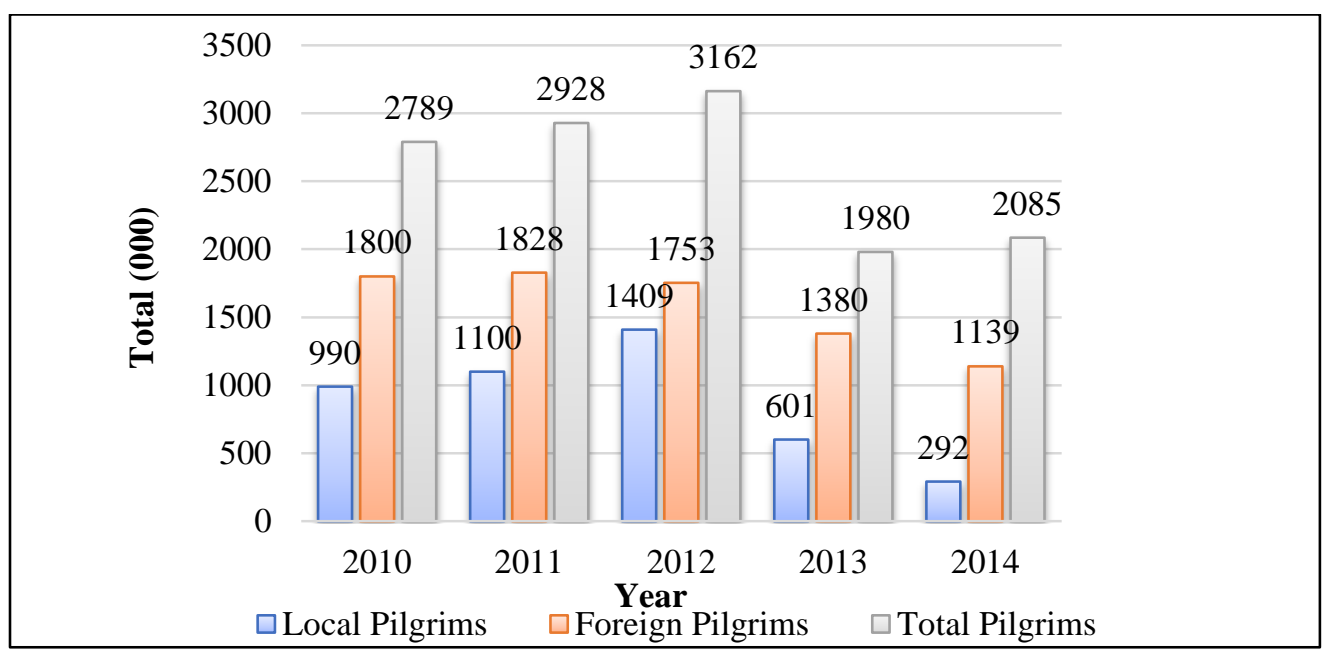

Figure 1: Numbers of Pilgrims in Mecca for the Year 2010 - 2014

Local pilgrims in Figure 1 refer to pilgrims from Saudi Arabia, while foreign pilgrims refer to pilgrims from countries other than Saudi Arabia. The data was taken from hajj statistics in year 2014 by the government of Saudi Arabia. Based on Figure 1, it can be seen the increasing number of Muslims who went on hajj pilgrim in 2011 and 2012 until it reaches to more than 3 million people. However, in 2013 depreciation has made the numbers shrunk to nearly 2 million people. However, a slight increase occurs in 2014. This situation is due to the work of enlarging and altering Masjid al-Haram in Mecca that forced the government of Saudi Arabia to lower the quota for pilgrims. This case was declared by the Governor of Mecca, Prince Khaled al-Faisal. According to him, the quota for Haj pilgrims must be cut to 20 percent for the foreign pilgrims and 50 percent for the Saudi Arabian pilgrims. However, the quota of hajj pilgrims will return to normal as well as the Masjid al-Haram renovation process is complete (BeritaHarian Online, 2013).

In such a situation, Mohammed Mohandes (2010), Alnizari (2011), al-Hashedi et al (2013) and RaziehHaghighati (2016) thought that situation will be a challenge to the Saudi government and any hajj pilgrim management organization involved to manage Hajj. Therefore, the Saudi government and organizations involved in hajj management requires an appropriate management concept to manage the pilgrims in Mecca that is always increasing. The question is what is the most appropriate concept of hajj pilgrim management? Given the pilgrims is related to Islam and Muslims, the management methods should be based on Islamic management. This is consistent with the view of Yusuf al-Qaradawi (1996), Muhammad SyukriSalleh (2003 \& 2009), and AbdusSattarAbbasi, Khasif Ur Rehman and Amna Bibi (2010).

According to Yusuf al-Qaradawi (1996), all Muslims activities shall be done only for sake of Allah SWT. At the same time, the ways for carrying out their activity shall also coincide with sharia rules that have been established by Allah SWT. As for Muhammad SyukriSalleh (2003 \& 2009), anything that has relation to Islam would not be reasonable if it is managed in a way that is not Islamic. On the contrary, when is not Islamic. In other words, both the management concept and the things that to be manage shall be based on Islamic way. AbdusSattarAbbasi, Khasif Ur Rehman and Amna Bibi (2010) took the view that all Muslims must practice the management practice brought by Prophet Muhammad SAW which is the management that based on Qur'an and hadith.

Based on that, this paper discusses the philosophy of hajj pilgrim management from the Islamic perspective with four important aspects. First, epistemology; second, ontology; third, axiology; and fourth, teleology. Hence, this paper discusses it in the following four sub-topics. 


\section{The Islamic Epistemological Perspective of Hajj Pilgrim Management}

Literally, the meaning of epistemology is the theory of knowledge and justification (Audi, 2003:1). From the point of terminology, it is a branch of philosophy that discusses the nature of knowledge, the justification of knowledge gained and its limitations, interpretation of knowledge and how to acquire knowledge (Ahmad Sunawari Long, 2008:127). From the context of epistemology, the Hajj is one of the pillars of Islam which is based from the most important source of knowledge in Islam, namely the Qur'an. It is prescribed since the time of Prophet Abraham AS and Prophet Ishmael AS (Muhammad SallehAwang, 1986:35; Haron Din, Ishak Din \& Abu Hassan Din, 2007:80-81). The prescribed is based on the verse of the Qur'an, which mean:

"And proclaim the pilgrims among men, they will come to thee on foot and (mounted) on every kind of camel, lean on account of journeys through deep and distant mountain highways." (Chapter al-Hajj, 22:27).

After the death of the Prophet Abraham AS and Prophet Ishmael AS, the hajj was mixed with polytheism and idolatry by the parties who were ignorant. To eliminate these acts, Allah SWT sent the Prophet Muhammad SAW to renew and resume the teachings brought by both prophets (Haron Din, Ishak Din \& Abu Hassan Din, 2007:80-81). Based on that situation, Allah SWT has made hajj as an obligation to Prophet Muhammad SAW and all Muslims who can afford it. In the second most important source of knowledge in Islam, which is the hadith of Prophet Muhammad SAW explains this. The Prophet said, which means:

"Islam is built on five pillars (which are) to testify that there is no god but Allah and that Muhammad is His slave and His messenger, pray, pay zakat, pilgrims to Baytu'Llah, and fasting in Ramadan." (Narrated by al-Bukhari, hadith no. 8).

The Muslim scholars have agreed that the pilgrims were first made compulsory in Islamic law in the sixth year of Hijrah (Muhammad SallehAwang, 1986:35). The obligation of it is also based on the word of Allah SWT says:

"In it are signs manifest (for example), the station of Abraham, whoever enters it attains security. Pilgrims thereto is a duty men owe to Allah - those who can afford the journey. But if any deny faith, Allah stands not in need of any of His creatures." (Chapter Ali 'Imran, 3:97).

To carry out the commands of Allah SWT, Prophet Muhammad SAW together with 1,500 companions went to Mecca for performing hajj. However, their goal was not achieved because they were stopped by the Quraysh and almost led to a fight. A negotiation has been made between the Prophet Muhammad SAW and the Quraysh which creates a common agreement known as the Treaty of Hudaibiyyah (Muhammad SallehAwang, 1986:35 \& M. SalihPutuhena, 2007:31).

After three years, which is in the ninth year of Hijra, only the hajj can be done by the Muslims. In that year, the Prophet Muhammad SAW had ordered his senior companion, Abu Bakr RA to go to Mecca for the pilgrims along with 300 Muslims. In the following year, the Prophet Muhammad SAW along with almost 100,000 Muslims going to Mecca for performing the hajj (Mohammad SallehAwang, 1986:36-41). Based on these historical facts, the importance of the hajj pilgrim management had already started by the Prophet Muhammad SAW and continued by his companions. In fact, based on the arguments on hajj pilgrims in the revelation of Islam has explain the importance of Islamic management for the pilgrims.

\section{The Islamic Ontological Perspective of Hajj Pilgrim Management}

Ontology revolved around the question of the scope of knowledge, whether limited to the physical world ('alam al-shahadah) or includes metaphysical ('alam al-ghayb) (Abdul Rahman Abdullah, 2005:19). Mukhtar Latif (2014:187) detailing the seven features of ontology. First, being (wujud); second, reality (haqiqah); third, existence (wujud); fourth, essence (mahiyah); fifth, substance (jawhar); sixth, change (harakah); and seventh, the one (wahdah) and the many (kathrah).

From the fourth aspect, the essence of hajj pilgrim management is based on the monotheistic view or tawhid. The hajj pilgrim management would not exist without faith, because it is a recognition that Allah SWT is the Lord of the worlds and Almighty over all creatures on this earth (Khurshid Ahmad, 1980; al- 
Faruqi, 2000). Tawhid also refers to the concept of oneness in the ontology which Allah SWT as the only God worthy of worship (Osman Bakar, 1991; Syed Muhammad Naquib al-Attas, 2005; Muhammad Abdullah \& Muhammad Junaid Nadvi, 2011).

Muhammad RasidMohdYadmanSarwan and S. SalahudinSuyurno (2008:32) details the meaning of tawhid as an acknowledgment, appreciation, and recognition that Allah SWT exists and the need for people to be submissive and obedient to Him. The case has been recognized since the time of Prophet Adam AS until the time of Prophet Muhammad SAW in relation with the recognition of the existence of Allah SWT and man must be submissive and obedient to Him.

According to Syed Omar Syed Agil (1997), tawhid is related to eight items. First, there is a God in heaven and on earth that is referring to Allah SWT. Second, Allah SWT is the Creator of the heavens and the earth and all that is between them. Third, Allah SWT is the owner of everything that exists on this earth. Fourth, Allah SWT is the giver of sustenance to every living thing. Fifth, Allah SWT is the administrator of each case. Sixth, the oneness of Allah SWT through the acts of worship. Seventh, obey and submit completely to Allah SWT and not worshipping others except Him, and eighth carry out the commands of Allah SWT in all aspects of life.

Based on the meaning of tawhid, it can be concluded that the understanding on the concept of tawhid among hajj pilgrim management officers is very important. There are at least eight implications when the concept of tawhid is internalized by any management system including in the hajj pilgrim management. First, it can produce Muslim's in an organization who are open minded, trustworthy, efficient and disciplined. Second, it can produce individuals who have self-esteem and self-confidence. Third, it can produce individuals who are humble and humility. Fourth, it will produce pious individual, brave and stand up to the truth. Fifth, produce individuals that will not give up easily when faced with any problems or failure. Sixth, build individuals who have patience, determination and passion. Seventh, to produce individuals with a good attitude, subsided and have no feeling for envy, greed and envy. Eighth, it can produce individuals who can comply with the rules and laws that have been stated by Allah SWT (Wan Liz Ozman Wan Omar, 1996).

\section{The Islamic Axiological Perspective of Hajj Pilgrim Management}

The term axiology comes from the Greek "axios" which mean values or ethics, and "logos" that brought the meaning of theory (Runes, 1976; Hart, 1971:29). Thus, literally, axiology means theory of values (Abdul Rahman Abdullah, 2010:106). In general, axiology is a description of the character and morals which includes several important features, namely the good and bad behaviour, right and wrong, matter related to means and ends, and things ought to be (IdzamFautanu, 2012:202). Thus, values become the base that shape attitudes, perceptions, internal power, individuality, progress and development of a community or an organization (Mustafa Daud, 1994:127). There are three values that are identified should be included in the axiology of hajj pilgrim management. First, excellence (ihsan); second, trust (amanah); and thirdly, justice ('adl).

\subsection{Excellence (Ihsan)}

The management of pilgrims also need to be done with the utmost faith. The value of excellence in faith or ihsan has features like doing things properly, show good behaviour, like to do good things, and has the sincerity, kindness, compassion and sympathy towards humans and other creatures (al-Mawdudi, 1965:562; Mohamed Branine\& Pollard, 2010). Ihsan from one side mean that God sees all human deeds whether it was done openly or confidentially (Mustafa Daud, 1994:148). Thus, a hajj officer must believe that any behaviour and management act is seen by Allah SWT. From another aspect, ihsan mean compassion, kind, and considerate in managing something. Allah SWT has promised paradise to His servants who have this quality. This coincided with the word of God, which mean:

"To those who do right is a goodly (reward). Yea, more (than in measure)! No darkness nor shame shall cover their faces! They are companions of the garden; they will abide therein (for aye)!" (Chapter Yunus, 10:26). 
The value of ihsan in the Qur'an also explained by the Prophet Muhammad SAW in the hadith. Among them, the hadith of Prophet Muhammad SAW with Archangel Gabriel AS when he was asked by the Archangel Gabriel AS, which mean:

"Then he (Archangel Gabriel) asked: 'O Messenger of Allah, what is ihsan?' Prophet Muhammad said: '(Ihsan) is that you worship Allah as if you see Him. If you cannot see Him, definitely He (Allah) will see you'." (Narrated by al-Bukhari, hadith no. 48).

Thus, ihsan is when the soul and intellect realize that Allah SWT is seeing, listening, evaluating, administering, and managing the human. Ihsan can be divided into two main scopes which are ihsan in worship and ihsan in daily transactions (mu'amalah). Ihsan in worship is when human worshipping Allah SWT with humility and sincerity as it seemed like he was dealing with Allah SWT. Ihsan in muamalah, also has two meanings. First, ihsan is a benefit to which the care of particular interest that should be owned by certain parties and enhance the quality of the work. This understanding is reflected in the Muslim family affairs and community (AzmanChe Omar, 2001:62; Hassan Ahmad, 2008:209; Mohamad Zamri Mohamed Shapik, 2014).

For the second meaning, ihsan is viewed in the context of work and the management of the institution. Ihsan means to enhance the quality of work, a thorough knowledge and skills and developed strong skills and fully develop (Mohamad Zamri Mohamed Shapik, 2014). Nubli Mohammed Abdul Wahab (2008:24) specifically explain the meaning of ihsan is to provide more than the required tasks, works better than the assigned work, more time from the required time and provide the best service with sincerity without expecting anything in return. Finally, the hajj officer will be a person who can fulfil his responsibilities as an officer and at the same time, earn rewards as a result of the worship of Allah SWT.

Based on that statement, the practice of the concept of ihsan will produce officers who have attributes preferred by Allah SWT such as earnest, honest, punctual, and so on, because they know that they are working for Allah SWT. They feel that everything that is done is a worship, then his deeds will be monitored by Allah SWT even he cannot see Allah SWT. This means, ihsan is not only in religious aspect even in aspects of lives as Qur'an mentioned, which mean:

"(That is) those who remember Allah while standing, sitting and lying down, and reflect on the creation of the heavens and the earth, (saying): 'Our Lord! Surely, you have not created all these in vain. Glory be to You! Save us from the chastisement of the hellfire'." (Chapter Ali 'Imran, 3:191).

The value of ihsan in everyday life can be translated in the management of the pilgrims. Mohamad Zamri Mohamed Shapik (2014) states that there are four main components that must be emphasized that are knowledge, understanding and awareness, implementation, and appreciation. Through the appreciation of that, it can provide three benefits to the management of the pilgrims. First, avoiding the occurrence of irregularities in the performance of task. Second, senior managers became more responsible when assigning assignments to the hajj officers (AzmanChe Omar, 2001). Third, it makes the management team to always displaying good character, behaviour and speech that are pleasing the heart of the pilgrims. Thus, tolerance and forgiveness become the working culture that closer the ties between the management people and the pilgrims (Nor 'AzzahKamri, 2006).

\subsection{Trust (Amanah)}

Trust is something that must be preserved as it should and deliver something to those who deserve it. When someone fails to carry out the trust, he was treacherous because the objective of the trust is to achieve justice. The absolute justice is only for Allah SWT. However, the human also has the obligation to seek for trust. Trust cause peace and prosperity to the people (Haron Din, 2015:72; Rusli Ahmad, 2011:82). Islam considers the job and position given to a person in an organization is a responsibility (Ahmad Ibrahim Abu Sin, 1991:100). Occupation or position provided it is not a form of luxury or privilege for themselves. Rather it is a trust that would be questioned in the Hereafter. It is in line with the 
word of Allah SWR, which mean:

"O ye that believe! Betray not the trust of Allah and the Messenger, nor misappropriate knowingly things entrusted to you." (Chapter al-Anfal, 8:27).

"Come not nigh to the orphan's property except to improve it, until he attains the age of full strength; and fulfil (every) engagement, for (every) engagement will be enquired into (on the Day of Reckoning)." (Chapter al-Isra', 17:34).

The verses of the Qur'an clearly showed that Allah SWT commanded His servants to keep the trust given because the trust will be questioned in the Hereafter. Therefore, YaPEIM Management Academy (2005) pointed out that the trust given must be treated with responsibility. With a sense of responsibility, it is directly expressed admirable qualities such as sincerity and honesty (AzmanChe Omar, 2001:56).

The value of trust that is applied in the management of pilgrims can educate and strengthen the faith and nurture the human spirit to always be obedient and submissive to Allah SWT in all things, situations or work performed (Ahmad Ibrahim Abu Sin, 1991:316). A person who is given a trust in the organization of hajj pilgrim management should always take a good care of the trust and never use that trust to commit a crime and fraud for personal gain. There are several advantages obtained if the management team maintaining the trust.

Among it, it can create a positive attitude among the management. Assignments can be implemented without the need to be frequently ordered as well it will produce the management team who are faithful and committed to manage the pilgrims (Muhammad RasidMohdYadmanSarwan\& S. SalahudinSuyorno, 2008:53). In addition, through the trust, it also can educate the faith and to preserve the soul of the management people to always fear of Allah SWT in whatever situation and tasks performed (Ahmad Ibrahim Abu Sin, 1991:105-106).

\subsection{Justice ('Adl)}

In terms of language, just means putting things in its place. Justice also refers to the balance and giving the right to the right people (Syed Othman Alhabshi, 1998:214). From the term perspective, fair means putting something in its place based on the faith, sharia and morals derived from the Qur' an and hadith (Mustafa Daud, 1994:148). Allah SWT emphasized the duty to administer justice in everything and in any situation. Justice does not mean equality. For example, the result of gender differences between men and women, so naturally there is a suitable job for a party and not suitable for the other. Hence, justice is always linked with equality. Justice in Islam is measured by the Qur'an and hadith and not interpreted according to human desires. The value of justice also led to an attitude that does not punish anyone for bias, not to abuse power, work with thoughtful, considerate towards one and will not give harm to others (Nor 'AzzahKamri, 2007:209). It is based on the Qur'an verse, which mean:

"O ye who believe! stand out firmly for Allah, as witnesses to fair dealing, and let not the hatred of others to you make you swerve to wrong and depart from justice. Be just, that is next to piety, and fear Allah. For Allah is well-acquainted with all that ye do."(Chapter al-Ma'idah, $5: 8)$.

In accordance with the word of Allah SWT, the hajj pilgrim management must always be in justice. Personal dissatisfaction with any pilgrims cannot be used as a reason not to be just. Muhammad RasidMohdYadmanSarwan and S. SalahudinSuyurno (2008) suggest four steps that demanded the hajj pilgrim management officers to be justice. First, in recruiting the officers shall elect officers that are really qualified and capable. Second, in delegating the task should take into account the talent, potential and strength of an officer. Third, in assessing officer should be done fairly and without injustice to any party. Fourth, in giving punishment to the officers it cannot be done selectively or by one position.

With the values of justice among the people in the management of the pilgrims, it will bring some positive effect. They are compatible with human nature that likes to be treated fairly. Hence, it can reduce discontent among management people and pilgrims. In addition, it can increase productivity in the hajj pilgrim management. In addition, it also can create a positive working culture towards progress and 
excellence in the management of hajj pilgrims (Muhammad RasidMohdYadmanSarwan\&S.SalahudinSuyurno, 2008).

\section{The Islamic Teleological Perspective of Hajj Pilgrim Management}

Teleology derived from the combination of two Greek words "telos" which means the end, and "logos" which means the study or theory (GhazaliBasri, 2012:25). From the terminology, teleology means the study of the end goal or also known as the theory of the end of world (al-Faruqi, 2000:13 \& 69). In this paper, teleology is discussed from the point of the ultimate goal as for every management, it has a goal to be achieved. Conventional management for example makes a profit, increase in revenue and productivity as a goal (Wan Liz Ozman Wan Omar, 1996; FadzilaAzni Ahmad, 2013:79).

The goal of this conventional management differs with the goal of Islamic management. According Azrin Ibrahim (2015), there are two views on Islamic management goals. First, al-falah, namely to achieve success and happiness in this world and the hereafter.Second, mardati'Llah that is getting the pleasure of Allah SWT. However, Azrin Ibrahim (2015) have concluded that the true goal of Islamic management is gaining the pleasure of Allah SWT based on the views by Muhammad SyukriSalleh (2003). According to Muhammad ShukriSalleh (2003), success and happiness in this world and hereafter will not be achieved if Allah SWT is not pleased. On the other hand, if Allah SWT is pleased, the success and happiness in this world and the hereafter can be achieved.

To gain the pleasure of Allah SWT does not exist in conventional management. The focus of conventional management is hovering in the planning, organizing, leadership, and control in order to achieve maximum profitability and produce high quality products (Ab Aziz Yusof, 2015:273). Therefore, based from the Islamic management, the ultimate goal in hajj pilgrim management is to gain the pleasure of Allah SWT. To obtain the pleasure of Allah SWT be used as the ultimate goal is because it directly gives satisfaction or success in this world and happiness in the hereafter (Muhammad SyukriSalleh, 2003:81; FadzilaAzni Ahmad, 2013:87; Hasan al-Banna Mohamed, Ab. Mumin Ab. Ghani \&SitiArniBasir, 2013).

In fact, it may also give space and opportunity for all members of the organization to continue to intensify their efforts to increase the commitment to continuously improving and progressing in the management (Ab Aziz Yusof, 2015:275). This commitment can be used synonymously and are aligned with the concept of "those who sacrifice themselves" (man yashrinafsahu) in the following verse:

"And there is the type of man who gives his life to earn the pleasure of Allah. And Allah is full

of kindness to (His) devotees." (Chapter al-Baqarah, 2:207)

Moreover, according to FadzilaAzni Ahmad (2013:91-92), the goal for the pleasure of Allah SWT can improve the spiritual aspect of the Hajj officers in the organization and management of pilgrims. This occurs through an increase in faith and a sense of servitude, the practice of sharia and morality. Not only that, if the management's activities in managing the pilgrims does not gain any profit in the form of money, however, hajj officers who expect the pleasure of Allah SWT still earn rewards in the form of rewards that leads to advantages in the hereafter. Finally, it can be concluded that the ultimate goal for the management of the pilgrims is to obtain the pleasure of Allah SWT. With the pleasure of Allah SWT, it will bring a positive impact on all the members of the organization in managing the pilgrims from physical and spiritual aspects.

\section{Conclusion}

The management of pilgrims should emphasize on philosophy as a basis of a management. This paper has discussed four aspects of the hajj pilgrim management philosophy which are from the aspect of epistemology, ontology, axiology and teleology. From the aspect of epistemology, philosophy can be understood that the prescribed of pilgrims derived from Qur'an and hadith as well the consensus of scholars. It also shows that the best pilgrims management should be based on the authoritative sources in Islam, not merely just by the conventional management philosophy that is used nowadays. From the 
ontological aspect, the management of pilgrims should have laid tawhid as the foundation of management. The hajj is the fourth pillar of Islam, means the hajj officers who take care of pilgrims needs to understand what underpin the Islamic management that is Oneness of Allah SWT and doing purely because of it. This has implications for other aspects of hajj pilgrim management philosophy which is axiology or value theory. This paper identified three important values that need to be internalized as part of the management that are ihsan, trust and justice. These values can indirectly establish mechanisms for sustainable hajj pilgrim management with the integration between spiritual and physical aspect. This will fulfil another aspect of the hajj pilgrim management philosophy which is teleology or theories about the ultimate goal. In the hajj pilgrim management, the ultimate goal to be underline in it philosophy is the pleasure of Allah or mardati'Llah. This objective implies that hajj officers who manage the pilgrims always do their task with full commitment to ensure their intent in managing is reserved.

\section{References}

Abdul Rahman Abdullah. (2005). Wacanafalsafahilmu: Analisiskonsepkonsepasasdanfalsafahpendidikannegara. Kuala Lumpur: Utusan Publications \& Distributors.

Abdul Rahman Abdullah. (2010). Wacanafalsafahsains: Sejarahdanpemikiran. Pulau Pinang: PusatKajianPengurusan Pembangunan Islam, UniversitiSains Malaysia.

AbdusSattarAbbasi, KashifurRehman, Amna Bibi. (2010). Islamic managementmodel. African Journal of Business Management, 4(9), 1873-1882.

Ahmad Ibrahim Abu Sin.(1991). Pengurusandalam Islam. (Trans. Abd Rashid Ngah\&JusohKadir). Kuala Lumpur: Dewan Bahasa danPustaka.

Ahmad Sunawari Long. (2008). Sejarahfalsafah(2 ${ }^{\text {nd }}$ Ed.). Selangor: PenerbitUniversitiKebangsaan Malaysia.

Al-Faruqi, Ismail. (2000). Al-tawhid: Kesannyaterhadappemikirandankehidupan (Trans. Unit Terjemahan Modal Perangsang). Selangor: International Institute of Islamic Thought \& Thinker's Library.

Al-Hashedi A. H., Muhammad Rafie Mohd Arshad, Hasimah Mohamed \& Ahmad Suhaimi Baharudin. (2013). RFID applications in Hajj management system.Proceeding of the 2013 IEEE International Conference on RFID Technologies and Applications.

Al-Mawardi (1996).Al-ahkam as-sultaniyah: The laws of Islamic governance (Trans. Asadullah Yate). London: Ta-Ha Publishers.

Al-Mawdudi, Abu al-A'la.(1965). Cara hidup Islam.(Trans. Wan Salim Muhammad Nur). Shah Alam, Selangor: Dewan PustakaFajarSdn Bhd.

Alnizari, Nezar Amer. (2011). A real-time tracking system using RFID in Mecca.Unpublished Master thesis.Massey University.

Audi, R. (2003). Epistemology: A contemporary introduction to the theory of knowledge. New York: Routledge.

AzmanChe Omar. (2001). Pengurusan di Malaysia dariperspektif Islam. Kuala Lumpur: Dewan Bahasa Dan Pustaka.

Azrin Ibrahim (2015). Asas-AsasHisbahdalamKitab al-Hisbah fi al-Islam: Kajian di MPKB-BRI, Kelantan. Unpublished $\mathrm{PhD}$ thesis.UniversitiSains Malaysia, Pulau Pinang.

BeritaHarian Online.(2013). Kerajaan Arab Saudi mahucontohipengurusan haji Malaysia.Accessed fromhttp://www/bharian.com.my/bharian/articles/kerajaanarabsaudimahucontohipengurusanhajim alaysia/article/index.html.

FadzilaAzni Ahmad. (2013). Konseppengurusaninstitusipembangunanberteraskan Islam. Kuala Lumpur: Dewan Bahasa danPustaka.

GhazaliBasri. (2012). Falsafahpendidikan Islam: Huraiankonsepdanaplikasi. Negara Brunei Darussalam: PusatPenerbitanKolejUniversitiPerguruan

Haron Din, Ishak Din \& Abu Hassan Din.(2007). Dato' Dr.Haron Din menjawabpersoalanfikahharian. Selangor: PTS Publication.

Haron Din. (2015). Manusiadan Islam: Jilid 1. Kuala Lumpur: Dewan Bahasa danPustaka.

Hart, S. L. (1971). Axiology: Theory of values. Philosophy and Phenomenological Research, 32(1), 2941. 
Hasan al-Banna Mohamed, Ab. Mumin Ab. Ghani \&SitiArniBasir. (2013). The guidance of moral values towards the consolidation of the quality management system according to the Islamic perspective. International Journal of Business and Social Science, 4(4), 254.

Hassan Ahmad. (2008). Institusi Islam. Kuantan: PenerbitUniversiti Malaysia Pahang.

IdzamFautanu. (2012). Filsafatilmu: Teoridanaplikasi. Jakarta: Referensi.

Khurshid Ahmad. (1980). Economic development in Islamic framework. In Khurshid Ahmad (ed.), Studies in Islamic economics (pp.177-188).Jeddah: International Centre for Research in Islamic Economics, King Abdul Aziz University.

M. ShalehPutuhena. (2007). Historiografi haji Indonesia. Yogyakarta: LKIS Yogyakarta.

Mohamad Zamri Mohamed Shapik.

Penghayatankonsepihsankearahmelahirkantenagakerjaberprestasitinggi.In KonvensyenLatihan Islam PeringkatKebangsaan Kali Ke-3.Bangi: InstitutLatihan Islam Malaysia.

Mohamed Branine\& Pollard, D. (2010). Human resource management with Islamic management principles: A dialectic for a reverse diffusion in management. Personnel Review, 39(6), 712-727.

Mohammed Mohandes. (2010). A case study of an RFID-based system for pilgrims identification and tracking. In Turcu, C. (ed.), Sustainable radio frequency identification solutions (pp. 356). Croatia: INTECH.

Muhammad Abdullah \& Muhammad Junaid Nadvi. (2011). Understanding the principle of Islamic worldview. The Dialogue, 4(3), 268-289.

Muhammad Nubli Abdul Wahab. (2008). Kecemerlanganpengurusanorganisasidalam Islam. Kuantan: PenerbitUniversiti Malaysia Pahang.

Muhammad SallehAwang. (1986). Haji di Semenanjung Malaysia: Sejarahdanperkembangannyasejaktahun 1300-1405H (1886-1985M). Kuala Terengganu: Syarikat PercetakanYayasan Islam Terengganu.

Muhammad SyukriSalleh. (2003). 7 prinsippembangunanberteraskan Islam. Kuala Lumpur: Zebra Editors.

Muhammad SyukriSalleh. (2009). Kearahpengurusanpembangunan Islam. In Muhammad SyukriSalleh\&FadzilaAzni Ahmad (eds.), Pengurusanpembangunan Islam: Prosiding seminar. Pulau Pinang: UniversitiSains Malaysia.

Mukhtar Latif. (2014). Orientasikearahpemahamanfilsafatilmu. Jakarta: KencanaPrenadamedia Group. Mustafa Daud. (1994). Pengantarpolitik Islam. Kuala Lumpur: Dewan Bahasa danPusataka.

Nor 'AzzahKamri. (2006). Pengurusansumbermanusiamenurutperspektif Islam: Falsafahdanetikapelaksanaan. In Ab. Mumin Ab. Ghani \&FadillahMansor (eds.), Dimensipengurusan Islam: Menguruskerjadanmengurus modal insan (pp.83-101). Kuala Lumpur: PenerbitUniversiti Malaya.

Nor 'AzzahKamri. (2007). Pelaksanaankodetika Islam di institusipembangunanberteraskan Islam: Kajiankes di LembagaTabung Haji Malaysia. Unpublished PhD thesis.UniversitiSains Malaysia.

Osman Bakar. (1991). Tawhid and science: Essay on the history and philosophy of Islamic science. Pulau Pinang: Secretariat for Islamic Philosophy and Science.

Rasid Muhamad, MohdYadmanSarwan\&S.SalahudinSuyurno. (2008). Pengurusan Islam: Teoridanpraktis. PusatPenerbitanUniversitiUiTM.

RaziehHaghighati. (2016, April).Towards a safer Hajj season: Explorative modeling using direct-event simulation. Paper presented at Regional Conference on Hajj Best Practices (RCHAJJ'16), Penang.

Runes, D. D. (1976).Dictionary of philosophy. New Jersey: Littlefield, Adam and Co.

Rusli Ahmad. (2011). Konseppersonalitiungguldanciri-ciripekerjacemerlang. In AbdJalilBorham, Ahmad FazrullahMohd Zainal Abidin, Hassan Ahmad, \&Munira Abdul Razak (eds.), Mengangkasa modal insan: Isudancabaran. Kuantan: PenerbitUniversiti Malaysia Pahang.

Saudi Arabia Government. (2014). Accessed from http://www.cdsi.gov.sa/pdf/Hajj1435.pdf

Syed Muhammad Naquib al-Attas. (2005). Islamic philosophy: An introduction. Journal of Islamic Philosophy, 1, 11-43. 
Syed Omar Syed Agil. (1997). Pengurusanbadankorporatdannilai Islam. Kuala Lumpur: Nurin Enterprise.

Syed Othman Alhabshi.(1989). Islam, ekonomidanpengurusan. Shah Alam, Selangor: PenerbitanHizbi.

Wan Liz Ozman Wan Omar. (1996). Pengurusan Islam abad ke-21: Revolusipengurusanuntukkeunggulansektorawamdankorporat. Kuala Lumpur: Utusan Publications and Distributors.

YaPEIM Management Academy (2005).Pengurusandalam Islam menghayatiprinsipdannilaiQurani. Kuala Lumpur: Yayasan Pembangunan Ekonomi Islam Malaysia.

Yusuf al-Qaradawi.(1996). Memahamikeutamaanberasaskan al-Qur'an dan al-sunnah.(Trans. BahruddinFannani).Petaling Jaya: AngkatanBelia Islam Malaysia. 